\title{
sciendo
}

Research Article

(C) 2019 Mateja Berčan and Marija Ovsenik. This is an open access article licensed under the Creative Commons Attribution-NonCommercial-NoDerivs License (http://creativecommons.org/licenses/by-nc-nd/3.0/).

\section{Intergenerational Learning: A Cornerstone of Quality Aging}

\section{Mateja Berčan}

Alma Mater Europaea

Evropski Center Maribor

\section{Marija Ovsenik}

Prof. Emeritus, PhD.

Doi: 10.2478/jesr-2019-0014

\section{Abstract}

The presentation of the professions from the older generation to elementary school pupils is one of the segments of intergenerational learning and intergenerational cooperation. Young people meet a person who actually did a particular occupation or profession. The older generation explains to the young generation what is needed to learn for a particular profession, and the young generation have the opportunity to test, or at least monitor the work they would do in the profession. The aim of our survey was to confirm that intergenerational learning is one of the cornerstones of quality aging. The data was collected with the survey questionnaire, which 200 representatives of older generation aged 65 and more have answered and was then quantitatively analyzed using a quantitative methodology. The results of the research confirmed that intergenerational cooperation through intergenerational learning, which involves the presentation of a profession of older generation to younger generation, affects the quality of life in the third life period. We can conclude that within intergenerational learning older generation gets the opportunity to transfer their knowledge, experience and share it with young generation, which leads to a higher quality of life even in the third stage of life. The younger generation is able to acquire concrete and useful information about professions first hand and in addition learn about aging and social tolerance.

Keywords: Intergenerational cooperation, intergenerational dialogue, presentation of the profession, quality of life

\section{Introduction}

Demographic structure is changing; long-term population projections show increase in the share of the older population in the developed world (EUROPOP2015). The aging of the population has a strong impact on relations between generations. Attitudes towards aging and older people are formed at an early age (Kornadt \& Rothermund, 2011), children already have a negative and stereotyped attitude towards older generation (Gilbert \& Riketts, 2008). In industrial societies, the modernization and rapid development of technology led to a change in the role of older people and increased the alienation of generations (Lyons, 2009). After the termination of employment, older people are labeled as people of reduced material standard and reduced social contacts. The prevailing viewpoint is that the elderly are primarily a social burden, and they often experience isolation, which is the source of various conflicts and creation of negative stereotypes (Cotten et al., 2013). Fivush et al. (2011) stress that the quality of life and the future of the next generations depend on cooperation and coexistence between generations. In response to an increased gap between generations, scientists (Philips et al., 2010) highlight intergenerational collaboration as one 
of the foundations of intergenerational connectivity, which leads to understanding and tolerance between generations. Intergenerational cooperation can thus be defined as a mechanism that encourages interaction between the older and the younger generation through participation in organized activities. One of the activities is also to acquaint pupils of elementary schools with different professions in the context of intergenerational learning.

\section{Theoretical Framework}

Today, the modern way of life is increasingly separating generations - especially the younger and the older generation. Life in multigenerational communities is becoming more and more rare, and therefore it is not possible to expect the establishment of everyday dialogue - especially between the older generation and the younger generation (MDDSZ, 2006). According to the study by Plumb (2014) intergenerational learning is influencing the relationships between older and younger generations (primary school students) and reduces the growing gap between the generations. By involving elementary school students in the activities of the older generation, for example, in homes for the elderly, we can notice that both the younger generation and the older generation have something to offer each other and also learn a lot from one another. In the resource where the impact of intergenerational programs on generations was studied, it was found that intergenerational programs contribute to reducing the generation gap and promote positive relationships between the older and the younger generation (Bales and other, 2010).

The older generation faces a number of changes - from adjusting to retirement and problems with accepting changes in social status, to feeling inferior and socially subordinate. Suddenly, in the third life period, a person has too much or too little time and his circle of social contacts narrows. All this results in feelings of loneliness, remoteness and of being irrelevant (Postružnik, 1999). In the research that Teater (2016) did it was noted that older people participating in intergenerational learning programs have gained self-esteem and social skills, which contributed to the improvement of both psychological and general health, and provided a sense of greater association with the community and therefore in quality of life. And also some other researches (Možina and others, 2013) found that the participation of older people in intergenerational learning is one of the important ways that lead to their reintegration into society.

Intergenerational learning enables the participation of different generations in activities that promote intergenerational dialogue and where generations engage in the acquisition of skills, values and knowledge. It is one of the ways of managing demographic change and importantly, it contributes to the development of social capital and social cohesion in aging societies. As Merriam and Kee (2013) argue: active and healthy older people, with their rich life experiences and their expertise, make a significant contribution to community development.

According to Hoff (2007), the intergenerational learning was a means of transferring knowledge, skills, competences, norms and values for centuries, and is as old as humanity itself. Younger generations adopting important positive experiences from the older generation leads to the advancement of human culture.

On the European Map of Intergenerational Learning (EMIL) website, intergenerational learning is defined as an opportunity that everyone, regardless of the age, can learn from one another; it is an important part of lifelong learning, where generations are involved in the acquisition of skills, values, and knowledge (EMIL, 2017).

The first systematic and formally designed intergenerational learning programs that emerged in the late 1970s were an integral part of social design models (Hanks \& Icenogle, 2001). The main purpose of these programs, which included non-biologically related old and young people, was to promote social growth, learning and emotional stability, which is often the characteristic of the relationship between the older and the younger family members. Newman \& Hatton-Yeo (2008) substantiate a new intergenerational paradigm of learning and introduce social capital associated with intergenerational learning.

Intergenerational learning programs include planned activities that connect different generations to share experiences (Newman \& Hatton-Yeo, 2008), with the aim of promoting understanding and respect between generations and building social cohesion (Hatton-Yeo, 2007). 
In such programs, older generation can work as mentors, helping young people, or vice versa, young people who help the older generation.

As soon as in the early childhood, children begin to get familiar with different occupations. They get to know them by watching their parents or close relatives and friends. Presentations of professions are also organized in the schools. The first turning point when children need to think more seriously about their career path is at the completion of elementary education. Depending on their psychosocial maturity and the expression of educational tendencies, the decision is demanding. Therefore, the society should be as innovative as possible in aiding them in the decision-making process - either through clear presentations of professions already in the process of elementary education, or through visits to organizations where professions of interest are carried out. One of the more innovative solutions is the inclusion of the older generation in the presentation of professions in elementary schools where the older generation would represent the profession as their own success story.

In our opinion, such approach would have a dual impact on both generations:

- the older generation would gain self-esteem, a sense of social significance and, ultimately, would enrich their quality of life;

- furthermore, the younger generation would get information about particular profession and at the same time the understanding of valuable contribution of the older generation.

In the review of foreign and domestic scientific literature, research on intergenerational learning, where the older generation would present professions to elementary school students, cannot be found. Also, there are no programs that would include older generation's presentation of profession, derived from their own practical experiences in any of the existing forms of intergenerational learning in Slovenia.

\section{Methodology}

The survey was based on a quantitative method; we collected data using a questionnaire. The research sample was purpose-based, consisting of 200 representatives of older generation, aged 65 years and more. Data for the survey was collected on a sample of the population from Slovenia. Participation in the survey was voluntary and anonymous, and the respondents were explained the purpose and aim of the study.

As an instrument, we used the questionnaire, developed for the needs of our research, which contained 20 questions. We divided it into two parts. The aim of the first part was to obtain demographic data, which led to determination of the characteristics of the sample and concluded its representability. In the second part we wanted to determine the attitude that the older generation presenting their professions to the younger generation has and determinate the impact of intergenerational cooperation through intergenerational learning on the quality of life in the third life period.

\section{Findings}

When asked about the need for "intergenerational cooperation" respondents answered by $98.5 \%$ that the younger generation needs more cooperation and advice from the older generation. In the second part, we studied the viewpoints of representatives of older generation, using the Likart scale (5 items) to determine the most important factors of quality age according to their opinion. The value of the coefficient of reliability in the case of the stated claims about the quality of life in the third stage of life the Cronbach's Alpha was 0,810 . This value indicates good reliability and allows the combination of variables. The reliability test showed that the most appropriate factor structure consists of two latent factors $(\mathrm{KMO}=0.755)$, which means that the indicators are divided into two components. The first component consists of: independent life, being useful, maintaining contact with family, neighborhood and peers, and physical health and vitality. We combined these components into the "quality of life" factor. The second component consists of transferring wisdom, experience and knowledge to the younger generation. We called the factor "teaching the younger generation". 
In the sequel, Pearson's correlation coefficient measured the strength of the relationship between the variables "intergenerational cooperation" and "quality of life", and between the variables "intergenerational cooperation" and "teaching the younger generation". In both cases, there is a proven link between variables; since in the first case the value of the correlation coefficient is -0.537 in the second case is 0.145 . The regression analysis followed and according to representatives of older generation involved in lifelong learning activities and programs, proved that "intergenerational cooperation" (-0.540) affects the "quality of life" of the elderly in the third life period.

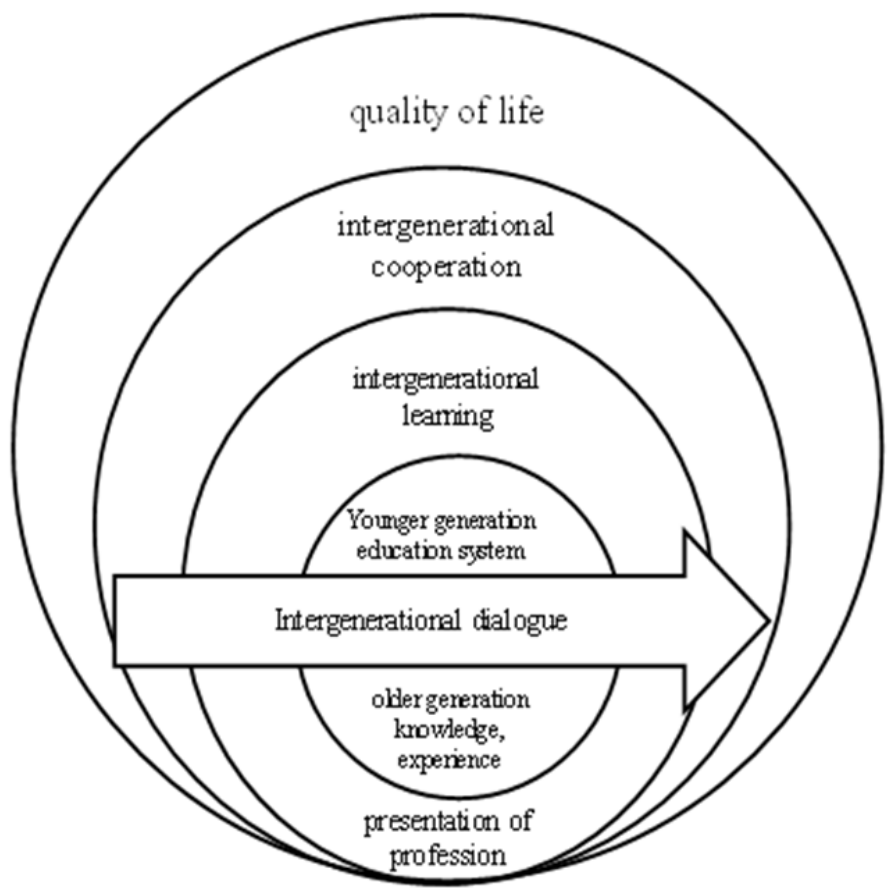

Figure 1: Model of intergenerational learning for a higher quality of life in the third life period from the perspective of representatives of older generation

Source: Researchers

\section{Conclusion}

Intergenerational learning enables the participation of generations in activities that promote intergenerational dialogue and enables generations to engage in the acquisition of skills, values and knowledge. It is one of the ways to cope with demographic change and it makes an important contribution to the development of social capital and social cohesion in aging societies.

Concerning the demographic change, the longevity of society, the results of the survey, and the literature review, we conclude that in the programs of intergenerational learning, the content and the presentation of professions, which would be represented by older generation to younger generation, should be included. We could also conclude that that would lead to a better mutual understanding between generations.

By presenting their profession to elementary school pupils, the older generations would be given the opportunity to share their experiences and knowledge. In social contact with the younger generation, the older generation would relive their youthful dimensions of life, resulting in a fuller and better quality life in the third life period. 


\section{References}

Bales, S., Eklund, S. \& Siffin, C. (2010). Children's perceptions of elders before and after a school-based intergenerational program. Educational Gerontology, 26 (7): 677-689. Available: http://www.ta ndfonline.com/doi/abs/10.1080/03601270050200662?journalCode=uedg20 (August 14, 2017).

Cotten, S., Anderson, W., \& McCullough, B. (2013). Impact of Internet Use on Loneliness and Contact with Others Among Older Adults: Cross-Sectional Analysis. Journal of Medical Internet Research. Available: http://www.jmir.org/2013/2/e39/ (October 18, 2017).

European Map of Intergenerational Learning: What is Intergenerational Learning. Available: http://www.emilnetwork.eu/what-is-intergenerational-learning/ (August 14, 2017).

EUROPOP2015: Population structure and ageing/SI, Available: https://ec.europa.eu/eurostat/statisti csexplained/pdfscache/64806.pdf (Marc 1, 2019).

Fivush, R., Bohanek, J., \& Zaman, W. (2011). Personal and intergenerational narratives in relation to adolescents' well-being. New directions for child and adolescent development, 131:45-57.

Hanks, R., \& Icenogle, M. (2001). Preparing for an Age-Diverse Workforce: Intergenerational Service-learning in Social gerontology and Business Curricula. Educational Gerontology, 27(1): 49-70.

Hatton-Yeo, A. (2007). Intergenerational Practise: Active Participation Across the Generations. Stoke on Trent. Beth Johnson Foundation.

Hoff, A. (2007). Intergenerational Learning as an Adaptation Strategy in Aging Knowledge Societies. European Commission ur. Education, Employment, Europe. Warsaw: National Contact Point for Research Programmes of the European Union, 126-129.

Kornadt, A., \& Rothermund, K. (2011). Dimensionen und Deutungsmuster des Alters. Zeitschrift für gerontologie und Geriatrie, 44(5): 291-298.

Gilbert, C., \& Ricketts, K. (2008). Children's attitudes toward older adults and aging: A synthesis of research. Educational Gerontology, 34(7): 570-586.

Lyons, I. (2009). Public perceptions of older people and ageing: A literature review. National centre for the protection of older people. Available: http://www.ncpop.ie/userfiles/file/ncpop\%20reports/ Review\%201\%20LR\%20Older\%20people\%20and\%20ageing.pdf (February 19, 2017).

Merriam, S., \& Kee, Y. (2013). Promoting Community Wellbeing: The Case for Lifelong learning for Older Adults. Sage: Adult Education Quarterly, 20IX, Vol XX(X):1-17.

Ministrstvo za delo, družino, socialne zadeve in enake možnosti RS. (2006). Nacionalna strategija skrbi za kakovostno staranje prebivalstva in za solidarno sožitje generacij $v$ Sloveniji. Available: http://www.mddsz.gov.si/fileadmin/mddsz.gov.si/ageuploads/dokumentipdf/strategija_staranje_sozitje_20 06_jrazprava_5_6_06.pdf (August 12, 2017).

Možina, T., Klemenčič, S., Jurič Rajh, A., \& Orešnik Cunja, J. (2013). Ekspertna zunanja evalvacija izobraževanja odraslih. Ljubljana: Andragoški center Slovenije.

Newman, S., \& Hatton-Yeo, A. (2008). Intergenerational Learning and the Contributions of Older People. Ageing Horizons, 8:31-39.

Philips, J., Ajrouch, K., \& Hillcoat-Nalletamby, S. (2010). Key Concepts in Social Gerontology. London: SAGE Publications Ltd.

Plumb, K. (2014). Intergenerationl Learning. Available: http://blogs.ubc.ca/kristaerinp/files/ 2014/08/Intergenerational-Learning-Krista-Plumb-FD.pdf (August 10, 2017).

Postružnik, A. (1999). Prostovoljno delo srednješolcev in osnovnošolcev - medgeneracijsko povezovanje. 2. slovenski kongres prostovoljcev. Ljubljana: Socialna zbornica Slovenije.

Teater, B. (2016). Intergenerational programs to promote active aging: the experiences and perspectives of older adults. Activities, Adaptation \& Aging, 40.1:1-19. 